\title{
Maternal Inflammation Disrupts Fetal Neurodevelopment via Increased Placental Output of Serotonin to the Fetal Brain
}

\author{
Nick Goeden, ${ }^{1}$ Juan Velasquez, ${ }^{1}$ Kathryn A. Arnold, ${ }^{5}$ Yen Chan, ${ }^{2}$ Brett T. Lund, ${ }^{3}$ George M. Anderson, ${ }^{6}$ \\ and Alexandre Bonnin ${ }^{4}$ \\ ${ }^{1}$ Neuroscience Graduate Program, Zilkha Neurogenetic Institute, ${ }^{2}$ Division of Maternal-Fetal Medicine, Department of Obstetrics and Gynecology, \\ ${ }^{3}$ Multiple Sclerosis Division, Department of Neurology, and ${ }^{4}$ Zilkha Neurogenetic Institute and Department of Cell and Neurobiology, Keck School of \\ Medicine of the University of Southern California, Los Angeles, California 90089, ${ }^{5}$ The University of Southern California, Los Angeles, California 90089, and \\ ${ }^{6}$ Child Study Center and Department of Laboratory Medicine, Yale University School of Medicine, New Haven, Connecticut 06519
}

Maternal inflammation during pregnancy affects placental function and is associated with increased risk of neurodevelopmental disorders in the offspring. The molecular mechanisms linking placental dysfunction to abnormal fetal neurodevelopment remain unclear. During typical development, serotonin (5-HT) synthesized in the placenta from maternal L-tryptophan (TRP) reaches the fetal brain. There, 5-HT modulates critical neurodevelopmental processes. We investigated the effects of maternal inflammation triggered in midpregnancy in mice by the immunostimulant polyriboinosinic-polyribocytidylic acid [poly(I:C)] on TRP metabolism in the placenta and its impact on fetal neurodevelopment. We show that a moderate maternal immune challenge upregulates placental TRP conversion rapidly to 5-HT through successively transient increases in substrate availability and TRP hydroxylase (TPH) enzymatic activity, leading to accumulation of exogenous 5-HT and blunting of endogenous 5-HT axonal outgrowth specifically within the fetal forebrain. The pharmacological inhibition of TPH activity blocked these effects. These results establish altered placental TRP conversion to 5-HT as a new mechanism by which maternal inflammation disrupts 5-HT-dependent neurogenic processes during fetal neurodevelopment.

Key words: inflammation/infection; neurodevelopment; placenta; prenatal programming; serotonin; tryptophan

Significance Statement

The mechanisms linking maternal inflammation during pregnancy with increased risk of neurodevelopmental disorders in the offspring are poorly understood. In this study, we show that maternal inflammation in midpregnancy results in an upregulation of tryptophan conversion to serotonin (5-HT) within the placenta. Remarkably, this leads to exposure of the fetal forebrain to increased concentrations of this biogenic amine and to specific alterations of crucially important 5-HT-dependent neurogenic processes. More specifically, we found altered serotonergic axon growth resulting from increased 5-HT in the fetal forebrain. The data provide a new understanding of placental function playing a key role in fetal brain development and how this process is altered by adverse prenatal events such as maternal inflammation. The results uncover important future directions for understanding the early developmental origins of mental disorders.

\section{Introduction}

Mechanistic links between maternal inflammation during pregnancy and the risk for developmental disorders in the offspring,

Received July 2, 2015; revised April 6, 2016; accepted April 13, 2016.

Author contributions: N.G., B.T.L., G.M.A., and A.B. designed research; N.G., J.V., K.A.A., B.T.L., G.M.A., and A.B. performed research; N.G., Y.C., B.T.L., G.M.A., and A.B. analyzed data; N.G., Y.C., B.T.L., G.M.A., and A.B. wrote the paper.

This work was supported by the US Department of Defense (Grant AR120066 to A.B.), the Conte Center Grants P50 MH096972 and P50 MH103222 (to A.B.), the Autism Science Foundation (Predoctoral Fellowship to N.G.), and the Rose Hills Foundation (Summer Research Fellowship to K.A.A.). We thank Yvette Kolodji, Alex Levy, and Giorgi Agadjanyian for technical assistance in collection and processing of samples for CBA data and Dr. Hsiao-Huei Wu (Department of Pediatrics, University of Southern California) for helpful discussions. including autism spectrum disorders (ASDs), cognitive delay, and schizophrenia, are being investigated intensively (Bonnin and Levitt, 2011; Stolp et al., 2011). Intrauterine bacterial infection was shown to be an independent risk factor for early autistic features (Limperopoulos et al., 2008) and systemic maternal viral

The authors declare no competing financial interests.

Correspondence should be addressed to Alexandre Bonnin, PhD, Zilkha Neurogenetic Institute and Department of Cell and Neurobiology, Keck School of Medicine of the University of Southern California, 1501 San Pablo Street, ZNI 429, Los Angeles, CA 90089. E-mail: bonnin@med.usc.edu.

DOI:10.1523/JNEUROSCI.2534-15.2016

Copyright $\odot 2016$ the authors $\quad 0270-6474 / 16 / 366041-09 \$ 15.00 / 0$ 
infection (e.g., influenza) has been reported as a risk factor for ASD and schizophrenia in the offspring (Patterson, 2002, 2009). These associations are observed for both vertically (i.e., from mother to fetus) and nonvertically transmitted pathogens, suggesting that maternal inflammation resulting from exposure to these pathogens in and of itself is sufficient to alter fetal neurodevelopment. In support of this possibility, elevated concentrations of soluble proinflammatory and chemo-attractive cytokines in the maternal serum have been linked to neurodevelopmental disorders in the offspring (Bell and Hallenbeck, 2002). Studies in rodents have demonstrated that systemic exposure to high doses of the immunostimulant polyriboinosinic-polyribocytidylic acid [poly(I:C)] induces a strong and sustained elevation in several proinflammatory cytokines, most notably interleukin-6 (IL-6), in the maternal serum. This dramatic induction of the maternal inflammatory pathway alters several neurodevelopmental processes and results in abnormal adult behavior in the offspring (Patterson, 2002, 2009; Wang et al., 2009). Intrauterine inflammation is observed in $\sim 20 \%$ of all pregnancies and a staggering $85 \%$ of very premature births, the latter of which has also been associated with a number of neurodevelopmental disorders (Elovitz et al., 2011). In addition, epidemiological observations of recent infectious diseases outbreaks (such as H1N1 influenza or Zika virus) suggest that pregnant women and their fetuses are high-risk groups for severe and long-lasting complications (Omer and Beigi, 2016). This highlights the need to investigate the causal mechanisms underlying maternal inflammation and fetal neurodevelopment.

During pregnancy, a fraction of the maternal TRP is converted to 5 -HT through the placental tryptophan hydroxylase (TPH1) enzymatic pathway, providing an exogenous source of 5-HT to the fetus. Prenatally, 5-HT modulates key neurodevelopmental processes, including axonal circuit formation (Gaspar et al., 2003; Bonnin et al., 2007, 2011; van Kleef et al., 2012; Brummelte et al., 2016). Another important placental TRP metabolic pathway is the conversion of TRP to kynurenine (KYN) by the indoleamine 2,3-dioxygenase (IDO1). This pathway protects the developing fetus from the maternal immune system at the early stages of pregnancy (Munn et al., 1998; Mellor and Munn, 2001). Although the effects of IDO1 induction on the KYN pathway have been studied, the effects of maternal inflammation on placental 5-HT synthesis and delivery to the fetus have not. Although moderate induction of the IDO1 and TPH1 pathway during pregnancy is important from an immunosuppressive (countering maternal rejection) standpoint, altered 5-HT output to the fetus may affect neurodevelopment significantly.

Here, we used a well established prenatal immune challenge in mice to study the effects of maternal inflammation in midpregnancy on TRP metabolism in the placenta and the downstream consequences on fetal brain development. Moderate doses of poly(I:C) were used to induce a mild maternal immune challenge that was shown previously to induce significant long-term brain and behavioral deficits in the adult offspring (Meyer et al., 2005; Meyer and Feldon, 2012). We observed that mild maternal inflammation during pregnancy leads to a transient increase of placental TRP concentration, followed by upregulation of Tph1 gene expression and increased TPH1 enzymatic activity in the placenta. These changes led to a sustained increase of placental 5-HT output to the fetus and ultimately increased 5-HT tissue concentration specifically within the fetal forebrain. Simultaneously, serotonergic axon outgrowth, a neurogenic process modulated by 5-HT signaling, was disrupted in this region. The pharmacological inhibition of TPH1 activity prevented the ef- fects of maternal inflammation on fetal serotonergic development. These findings suggest that fetal brain serotonergic development is highly sensitive to maternal inflammation through disruptions of placental TRP metabolism to 5-HT.

\section{Materials and Methods}

Animals and maternal immune activation. Pregnant female CD-1 dams (Charles River Laboratories) were injected intraperitoneally at embryonic day 12 (E12; the copulatory plug date is considered E1) with saline (0.9\% sterile solution; BD Biosciences, 297753) or $2 \mathrm{mg} / \mathrm{kg}$ poly(I:C) (Sigma-Aldrich, P9582) using $5 \mu \mathrm{l} / \mathrm{g}$ per pregnant dam. For pharmacological inhibition of TPH activity experiments, dams were injected intraperitoneally at E12 with either saline or poly(I:C) $(2 \mathrm{mg} / \mathrm{kg})$ and para-cholorophenylalanine (pCPA; 300 mg/kg; Sigma-Aldrich, C6506). Dams were anesthetized and fetal forebrain, hindbrain, placenta, tail samples, and serum were harvested as described previously (Bonnin et al., 2011). SRY genotyping for the purpose of analyzing sex differences was performed on all fetuses. Fetal tissues from each litter were either fresh frozen or fixed and randomly assigned to subsequent analyses. All procedures involving animals were approved by the Institutional Animal Care and Use Committee.

$q R T-P C R$ analysis. For mRNA expression analyses, three fresh-frozen fetal tissue samples from each dam were pooled and $40 \mathrm{mg}$ of tissue was extracted for RNA using the Bio-Rad Aurum Total RNA Mini Kit according to the manufacturer's specifications. Extracted RNA was quantified and tested for purity spectrophotometrically and RNA quality was assessed using an Agilent Technologies 2100 bioanalyzer with high sensitivity RNA Screentape. Only samples with an RNA integrity number of 8.5 or higher and a 260/280 ratio of 1.8-2.2 were used for subsequent qRT-PCR analysis. After quality assessment and quantification, $1 \mu \mathrm{g}$ of RNA was reverse transcribed to cDNA using the Invitrogen SuperScript III First-Strand Synthesis SuperMix for qRT-PCR kit according to the manufacturer's specifications. qRTPCRs were performed in triplicate using the Invitrogen Single Tube TaqMan Gene Expression Assays and TaqMan Gene Expression Master Mix and cycled and analyzed using the Invitrogen StepOnePlus Real-Time PCR System. Briefly, for each gene [Tph1 (Mm01202614_m1), Tph2 (Mm00557715_m1),Ido1 (Mm00492586_m1), Maoa (Mm00558004_m1), and reference gene TATA box binding protein (Tbp) (Mm00446973_m1)] and template combination $20 \mu \mathrm{l}$ reactions were set up in triplicate containing $10 \mu \mathrm{l}$ of TaqMan Gene Expression Master Mix, $1 \mu \mathrm{l}$ of TaqMan Gene Expression Assay, and $9 \mu \mathrm{l}$ of cDNA diluted in ultrapure water to a concentration of $10 \mathrm{ng}$ template per well. Once all reactions were set up in 96-well plates, they were transferred to the StepOnePlus thermocycler and run using standard cycling conditions of a $2 \mathrm{~min}$ hold at $50^{\circ} \mathrm{C}$, a $10 \mathrm{~min}$ hold at $95^{\circ} \mathrm{C}$, and 50 cycles of $15 \mathrm{~s}$ at $95^{\circ} \mathrm{C}$ followed by $60 \mathrm{~s}$ at $60^{\circ} \mathrm{C}$. Completed reactions were analyzed using the $2-\Delta \Delta$ CT method (Livak and Schmittgen, 2001). The $2-\Delta \Delta C T$ method for quantifying relative changes in gene expression involves comparing expression of a target gene with that of a reference gene that maintains stable expression throughout treatment groups and time points. Several reference genes were tested and TATA Box Binding Protein (Tbp) mRNA was found to be the most stable between treatment groups and time points in our samples. For the $2-\Delta \Delta \mathrm{CT}$ method to be valid, the amplification efficiencies of both the target and reference genes must be similar. To test this, efficiency curves for each TaqMan Assay were performed across a 100 -fold template dilution range and compared for each primer-template combination to ensure similarity. After amplification, the relative expression of the control samples was compared with that of the treated samples and expressed in terms of fold change.

In vitro 5-hydroxytryptophan (5-HTP) synthesis assays. Harvested tissues (placenta, forebrain, and hindbrain) were thawed on ice and homogenized ultrasonically in, respectively, 400,100 , or $80 \mu$ l of extraction buffer composed of $0.05 \mathrm{M}$ Tris buffer, $\mathrm{pH} 7.5$, containing $1 \mathrm{~mm}$ dithiothreitol and $1 \mathrm{~mm}$ EGTA. Homogenates were centrifuged at 21,000 $\times g$ for $15 \mathrm{~min}$ at $4^{\circ} \mathrm{C}$ and then assayed for tryptophan hydroxylase activity. Briefly, $20 \mu \mathrm{l}$ of supernatant was added to tubes containing $80 \mu \mathrm{l}$ of reaction or control buffer to give a final concentration of: $0.05 \mathrm{M}$ Tris buffer, pH 7.5, 1 mM EGTA, $50 \mu \mathrm{g} / \mathrm{ml}$ catalase, $200 \mu \mathrm{M}$ L-tryptophan, 100 $\mu \mathrm{M}$ ammonium iron (II) sulfate, and $100 \mu \mathrm{M}$ tetrahydrobiopterin (BH4; 
a cofactor required for TPH1 and TPH2 activity). Control buffers did not receive TRP or $\mathrm{BH} 4$. Tubes were incubated for $30 \mathrm{~min}$ at $37^{\circ} \mathrm{C}$ and reactions were terminated through protein denaturation by adding 100 $\mu \mathrm{l}$ of $0.2 \mathrm{M}$ percholoric acid with $100 \mu \mathrm{M}$ EDTA. Samples were stored on ice for $15 \mathrm{~min}$ to allow for complete protein denaturation and then centrifuged for $15 \mathrm{~min}$ at $21,000 \times g$ at $4^{\circ} \mathrm{C}$. TRP metabolism was determined by measuring the 5-HTP concentration using HPLC with electrochemical detection (see below). Protein concentration of the supernatants was determined using a detergent-compatible protein assay (Bio-Rad) and enzymatic activity was quantified as picograms of $5-\mathrm{HTP} / \mu \mathrm{g}$ of protein $/ 30$ min. Results are expressed as percentage of activity measured against salineinjected controls. Unless otherwise noted, all reagents were purchased from Sigma-Aldrich.

HPLC analysis. The HPLC analysis of perfusion samples and enzymatic assay supernatants was performed on an Eicom 700 system consisting of an ECD-700 electrochemical detector, an Eicom 700 Insight autosampler, and Envision integration software. An Eicompak SC-3ODS $3 \mu \mathrm{m}$ C18 reversed-phase column $(3.0 \times 100 \mathrm{~mm}$ inner diameter $)$ analytical column was used for separation. Samples were extracted in a 1:1 volume of $0.2 \mathrm{M}$ perchloric acid with $100 \mu \mathrm{M}$ EDTA and a volume of $10 \mu \mathrm{l}$ was injected into the column. The mobile phase used for separation consisted of $0.1 \mathrm{M}$ citric acid, $0.2 \mathrm{M}$ sodium phosphate dibasic, $7 \%$ methanol (JT Baker, 9093-03), and $5 \mathrm{mg}$ of EDTA in ultrapure water at a flow rate of $450 \mu \mathrm{l} / \mathrm{min}$. Unless otherwise noted, all reagents were purchased from Sigma-Aldrich. For measures of biogenic amine concentrations in fetal tissues, see Hervé et al. (1996) and Janusonis et al (2006) for detailed methodology.

Cytokine analysis. The maternal and placental inflammatory response to poly(I:C) or saline was quantified in every mouse by measuring the concentration of an array of cytokines and chemokines in serum or tissue homogenates at time of harvesting. Tissue concentrations were measured in the maternal serum, placenta, and fetal brains for the following cytokines/chemokines: CCL2-5, CXCL1, CXCL9, IL-1a/b, IL-2, IL-4, IL-6, IL-10, IL-17, IL-23, IFN $\gamma$, and TNF $\alpha$. For serum preparation, whole blood was collected and allowed to coagulate at $4^{\circ} \mathrm{C}$ for $30 \mathrm{~min}$ before centrifugation at $2000 \times g$ for $10 \mathrm{~min}$ at $4^{\circ} \mathrm{C}$. Serum supernatant was collected and stored at $-70^{\circ} \mathrm{C}$. Placental and fetal brain tissues were homogenized immediately upon collection in 3 volumes (microliters per milligram) of ice-cold PBS supplemented with commercially available protease inhibitor mixture (Cell Signaling Technology, 5871S). Homogenates were clarified by centrifugation at $12,000 \times g$ for $10 \mathrm{~min}$ at $4^{\circ} \mathrm{C}$, and then supernatants were collected and stored at $-70^{\circ} \mathrm{C}$. For assessment of solute concentrations, we used commercially available cytometric bead arrays (CBAs) (BD Biosciences) as described previously (Lund et al., 2004). To assay, all samples were thawed on ice, diluted 1:3 in the supplied dilution buffer, and then run in triplicate. The concentration of each solute was calculated based on a standard curve of known concentrations and the intra-assay variability accounted for using internal control samples. The CBA sample data were collected using a BD Biosciences Accuri cytometer and analyzed using the commercially available FCAP Array Software (BD Biosciences). The mean sample concentration from serum is given as picograms per milliliter and that from tissue as picograms per milliliter of tissue homogenate.

Ex vivo placental perfusion 5-HT synthesis assay. For perfusion experiments, a separate cohort of pregnant dams was injected with either saline $(n=4)$ or poly(I:C) $(n=4)$ at E12. Briefly, a single placenta per dam was harvested at E14 and quickly transferred to a thermostatically controlled incubation chamber at $37^{\circ} \mathrm{C}$. The uterine artery was cannulated with a $200-\mu \mathrm{m}$-diameter catheter and perfused at $20 \mu \mathrm{l} / \mathrm{min}$ with DMEM (Life Technologies, 11054-001) containing $200 \mu \mathrm{M} \mathrm{L}$-tryptophan and $100 \mu \mathrm{M}$ BH4. The umbilical artery was cannulated with a $105-\mu \mathrm{m}$-diameter catheter and perfused at $5 \mu \mathrm{l} / \mathrm{min}$ with DMEM. The eluate was collected from the umbilical vein for $90 \mathrm{~min}$ and analyzed for 5-HT concentration with HPLC. (For detailed methodology, see Goeden and Bonnin, 2013).

Neurodevelopmental assays. Fetal brains were dissected in ice-cold PBS, immediately transferred to $4 \%$ paraformaldehyde (PFA), and incubated at $4^{\circ} \mathrm{C}$ for $24 \mathrm{~h}$. The fetal brains were then incubated in $10 \%, 20 \%$, and $30 \%$ sucrose (dissolved in PBS) for $24 \mathrm{~h}$ each at $4^{\circ} \mathrm{C}$. After incubation, the brains were embedded in cryomolds on dry ice using Tissue Tek embed- ding medium (VWR, 25608-930) and stored at $-80^{\circ} \mathrm{C}$ until sectioning. Embedded brains were removed from the $-80^{\circ} \mathrm{C}$ freezer the night before sectioning and allowed to warm to $-20^{\circ} \mathrm{C}$. Fetal brains were sectioned coronally with a thickness of $20 \mu \mathrm{m}$ and sectioned tissue was stored at $-80^{\circ} \mathrm{C}$ until immunohistochemical analysis. Sections were permeabilized with $0.1 \%$ Triton X-100 in 2\% fetal bovine serum in PBS and incubated overnight at $4^{\circ} \mathrm{C}$ with primary antibodies: rabbit anti-5HT (final concentration $58 \mu \mathrm{g} / \mathrm{ml}$; Sigma-Aldrich, S5545). After extensive washing in PBS with $0.1 \%$ Triton X-100, slides were incubated at room temperature for $2 \mathrm{~h}$ with secondary antibody: Rhodamine Red-X-conjugated donkey anti-rabbit (1:800; Jackson ImmunoResearch Laboratories). Images were acquired with a Zeiss AxioCam MRm camera using Zeiss AxioVision version 4.8.2 software. 5-HT fluorescence intensity distribution was quantified using ImageJ. In every section, the fluorescence intensity was normalized to the background.

Statistical analyses. In all experiments, dams were treated as individual experimental groups ( 1 dam, $n=1)$ and fetuses $(n=3-5$ of either sex per dam) as biological repeats. For every measure, the number of dams used in each group is indicated in the figures. For cytokine analyses, qRT-PCR, HPLC, and enzymatic activity assays, the statistical significance of differences between groups was assessed using two-way ANOVA (followed by Bonferroni correction for multiple comparisons, assuming that significant $(p<0.05)$ main effects were observed), with time points and treatments used as variables. Unless otherwise noted, statistical differences presented are for treatment effects. For ex vivo placental perfusion experiments and PCPA treatment experiments performed at a single time point, differences between groups were compared using unpaired $t$ tests with the Holm-Sidak correction for multiple comparisons. For comparisons of 5-HT immunofluorescence distribution along the rostrocaudal extent of the fetal brain in the saline (control) group versus the poly(I: C)-treated group at a single time point, the Mann-Whitney $U$ test was used. No sex differences were observed in any of the analyses. All analyses were performed using GraphPad Prism version 6 software.

\section{Results}

Mild inflammation increases placental TRP metabolism and 5-HT delivery to the fetus

Pregnant dams were injected at E12 with $2 \mathrm{mg} / \mathrm{kg}$ poly(I:C) or saline solution (control) and the maternal, placental, and fetal inflammatory response was quantified in every mouse at time of harvesting (i.e., E12 +24 or 48 h). Of all cytokines tested, only the IL-6 concentration was significantly different in the maternal serum of poly(I:C)-treated dams compared with saline-injected controls (overall effect of treatment: $p=0.004, F=10.86, d f=$ 18 ) and only at the $24 \mathrm{~h}$ time point (increase of $92.3 \%$ over controls, $p=0.0002$ ). Importantly, despite the increased concentration of IL-6 in the maternal serum after poly(I:C) exposure, there was no change in fetal brain or placenta levels at 24 or $48 \mathrm{~h}$ (Fig. 1 A,B). qRT-PCR analysis revealed significant effects of maternal inflammation on TRP metabolic gene expression in the placenta (Fig. 1C,D). The most significant changes induced by poly(I:C) treatment over basal expression measured in controls obtained from saline-injected dams were observed for Ido1 (expression increased 4.2 -fold and 1.9-fold at the 24 and $48 \mathrm{~h}$ time points, respectively; overall significant effect of treatment: $p<$ $0.0001, F=707.0, d f=14$ ), followed by $T p h 1$ gene expression (increased 2.5-fold at $24 \mathrm{~h}$ and decreased 2.7 -fold at $48 \mathrm{~h}$; overall significant effect of treatment: $p<0.0001, F=31.58, d f=14$ ); there was no effect of poly(I:C) exposure on Maoa gene expression at either time point (no significant overall effect of treatment: $p=0.0855, F=3.424, d f=14)$. There was no significant effect of treatment on any TRP metabolic gene expression (i.e., Maoa, Ido1, or Tph2) in the fetal brain at either time point (data not shown).

To determine whether altered gene expression ultimately affects the placental conversion of maternal TRP to 5-HT, we mea- 
A

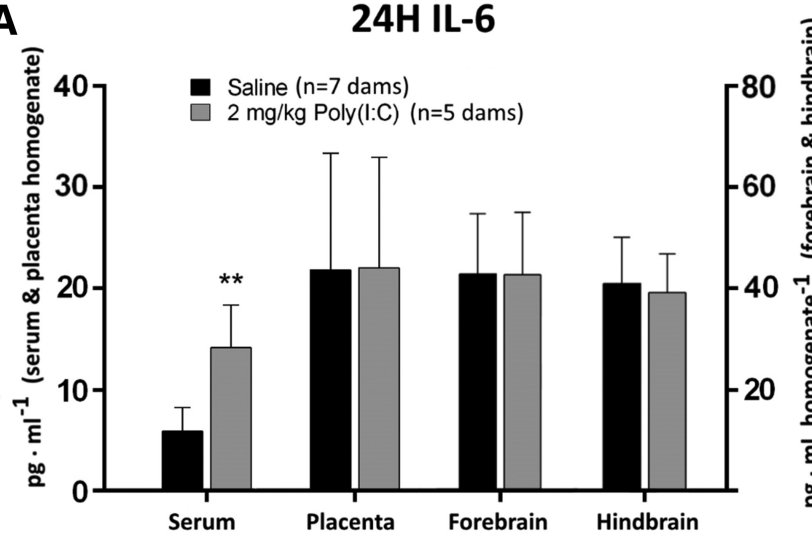

C

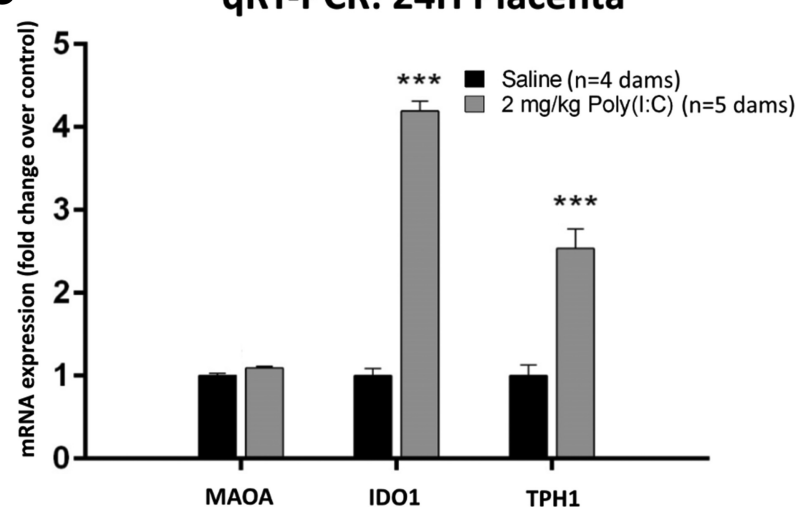

B

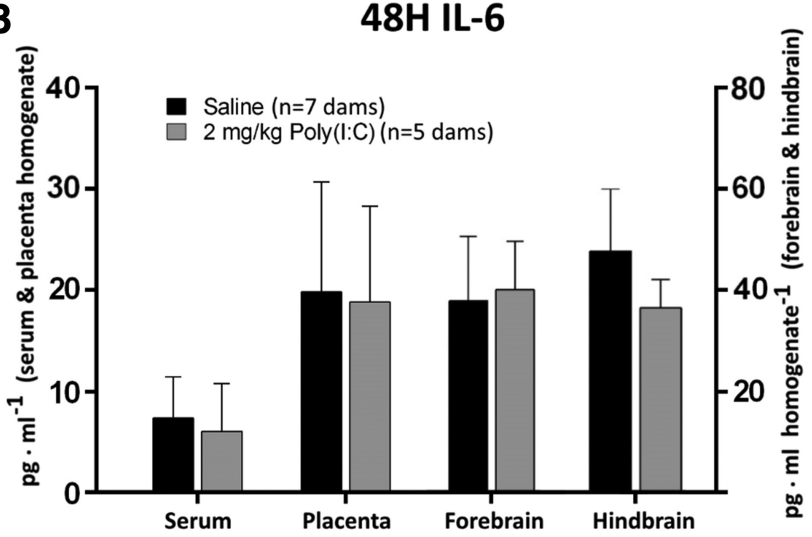

D

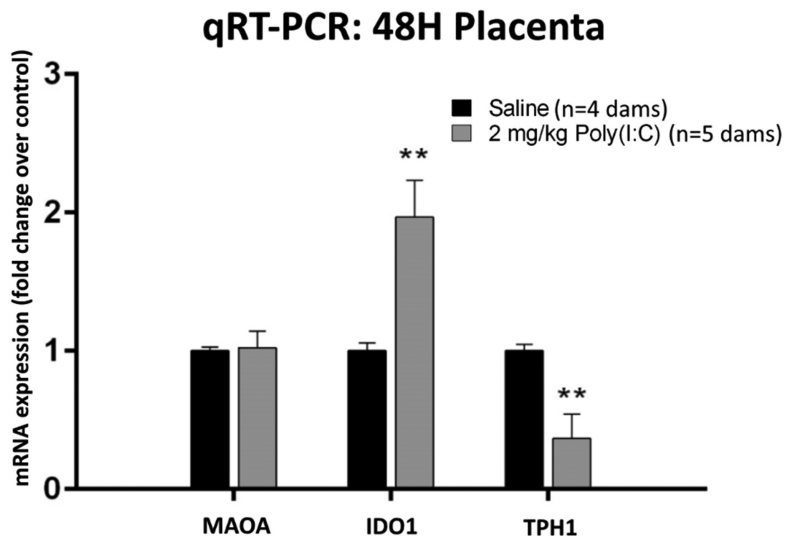

Figure 1. Maternal inflammation affects placental TRP metabolic gene expression. $A$, Twenty-four hours after $2 \mathrm{mg} / \mathrm{kg}$ poly $(\mathrm{l}: \mathrm{C})$ injection at E12, there is a significant increase of the proinflammatory cytokine IL-6 in the maternal serum, but not in the placenta or fetal forebrain/hindbrain. $\boldsymbol{B}$, Forty-eight hours after poly(l:C) exposure, maternal serum IL-6 levels have returned to baseline. C, Ido1 and Tph1 placental gene expression is significantly upregulated $24 \mathrm{~h}$ after poly(l:C) injection compared with saline (control). $\boldsymbol{D}$, Forty-eight hours after poly(l:C) injections, Ido1 gene expression is still significantly elevated and Tph1 gene expression is significantly reduced. ${ }^{* *} p<0.0005,{ }^{* * *} p<0.0001$, two-way ANOVA with Bonferroni correction. Error bars indicate SD. $n=3$ placentas per dam.

sured TPH1/2 enzymatic activity directly in placentas and brains harvested from a subset of the same litters. There was a significant effect of exposure to poly(I:C) on TPH1 activity in the placenta (overall significant effect of treatment: $p=0.0316, F=6.766$, $d f=8)$; TPH1 activity was significantly increased $48 \mathrm{~h}$ after treatment ( $p=0.009$ ) only. In contrast, TPH 2 enzymatic activity was not significantly altered by poly(I:C) exposure in the fetal hindbrain either 24 or $48 \mathrm{~h}$ after treatment (no significant overall effect of treatment: $p=0.3728, F=0.8913, d f=8$; Fig. $2 A$ ). To determine whether the increase in placental TPH1 enzymatic activity affects placental 5-HT synthesis and delivery to the fetus, we measured the real-time 5-HT output of ex vivo perfused placentas from saline- and poly(I:C)-injected dams. We observed a significantly increased $\left(t_{(6)}=2.7, p=2.0 \mathrm{E}-2\right)$ concentration of $5-\mathrm{HT}$ released into the umbilical vein when comparing placentas from poly(I:C) exposed dams with placentas from control dams (Fig. $2 B)$. These results demonstrate that a mild maternal inflammation induces a cascade of genetic and enzymatic changes within the placenta that result in increased 5-HT output to the fetus after $48 \mathrm{~h}$.

Fetal forebrain 5-HT increases rapidly after mild maternal immune activation

Consistent with previous findings that placental 5-HT synthesis affects fetal forebrain 5-HT concentration (Bonnin et al., 2011; Goeden and Bonnin, 2013), there was overall a significant effect of poly(I:C) treatment on fetal forebrain 5-HT tissue concentra- tion $(p=0.0028, F=14.71, d f=11$; Fig. $3 A, C)$; although 5-HT tissue concentration was elevated at both time points after poly(I:C) exposure, the increase was significant only $48 \mathrm{~h}$ after treatment (comparison with saline controls: $p=0.1342$ at $24 \mathrm{~h}$; $p=0.0130$ at $48 \mathrm{~h}$ ). The treatment had no significant effect on hindbrain 5-HT tissue concentration at either time point ( $p=$ $0.8094, F=0.0610, d f=11$; Fig. $3 B, D)$. Fetal brain tissue concentrations of 5-HIAA, the primary metabolite of 5-HT, remained unchanged at both time points $(p=0.1384, F=2.553$, $d f=11$ ). The concentration of 5-HTP in the fetal forebrain was below detection levels at these time points (data not shown). Poly(I:C) treatment also had a significant overall effect on KYN tissue concentration in the fetal forebrain $(p=0.0022, F=15.67$, $d f=11$; Fig. $3 A, C)$ and hindbrain $(p=0.0208, F=7.263, d f=$ 11 ; Fig. $3 B, D)$. Importantly, there was an overall effect of poly(I:C) exposure on placental TRP concentration $(p=0.0058$, $F=11.67, d f=11$; Fig. $3 E)$, with a significant increase at $24 \mathrm{~h}$ (1.4-fold over saline-injected controls, $p=0.0006)$, but not $48 \mathrm{~h}$ $(p>0.9999)$. To test the possibility that increased substrate (TRP) availability in the placenta $24 \mathrm{~h}$ after poly(I:C) injection leads to increased metabolic conversion to 5-HT, we performed dose-response studies in placentas $24 \mathrm{~h}$ after poly(I:C) or saline injections. The in vitro enzymatic activity assays demonstrated that increasing input concentrations of TRP led to a linear increase of 5-HTP production in both the saline $\left(r^{2}=0.9996\right)$ and poly(I:C) $\left(r^{2}=0.9972\right)$ groups. Therefore, placental 5-HT synthesis is correlated linearly to TRP substrate availability (Fig. 3F). 

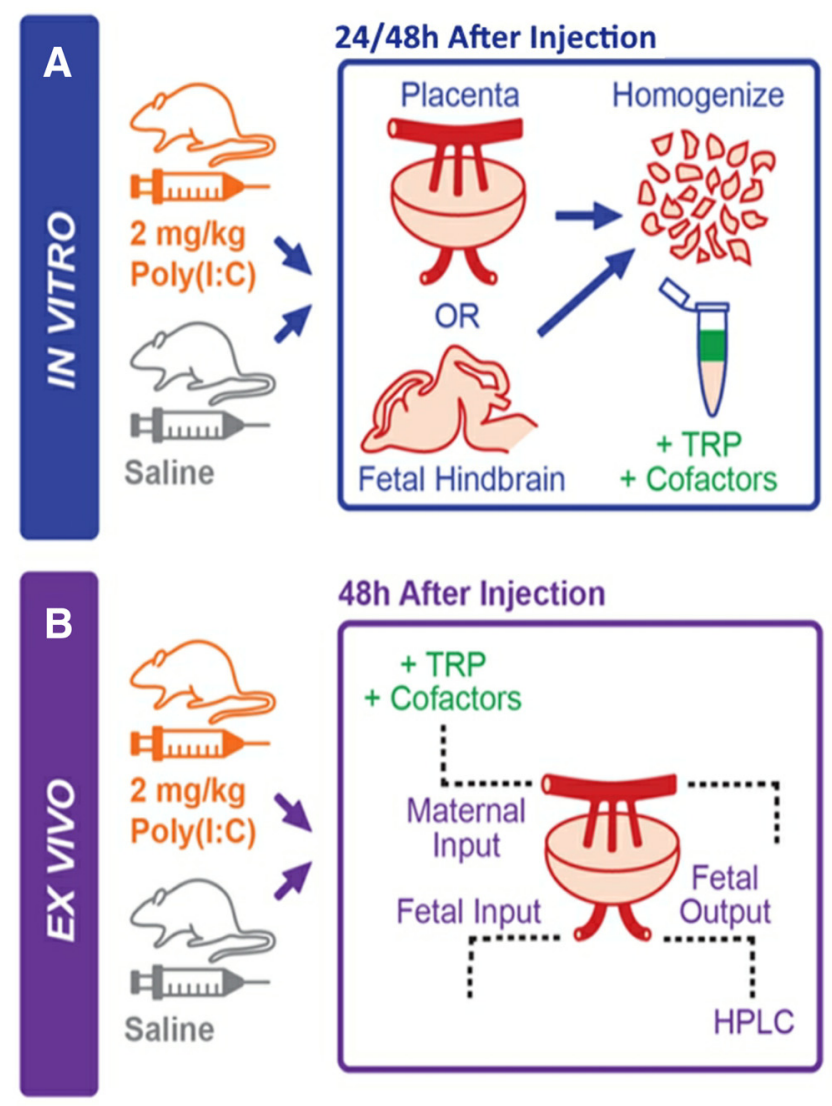

48h After Injection

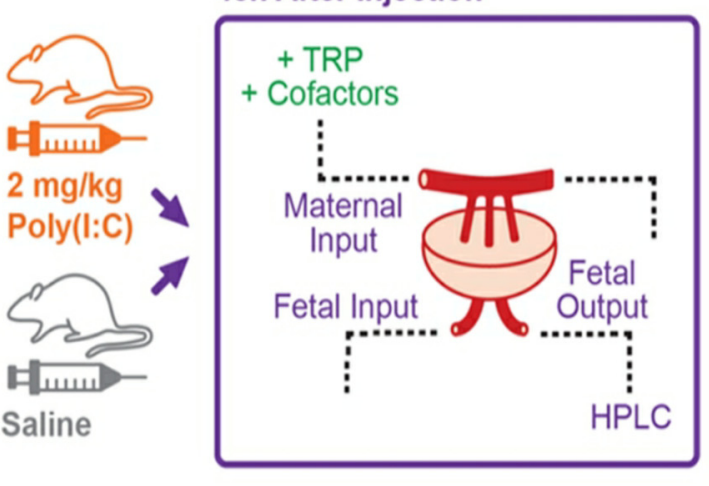

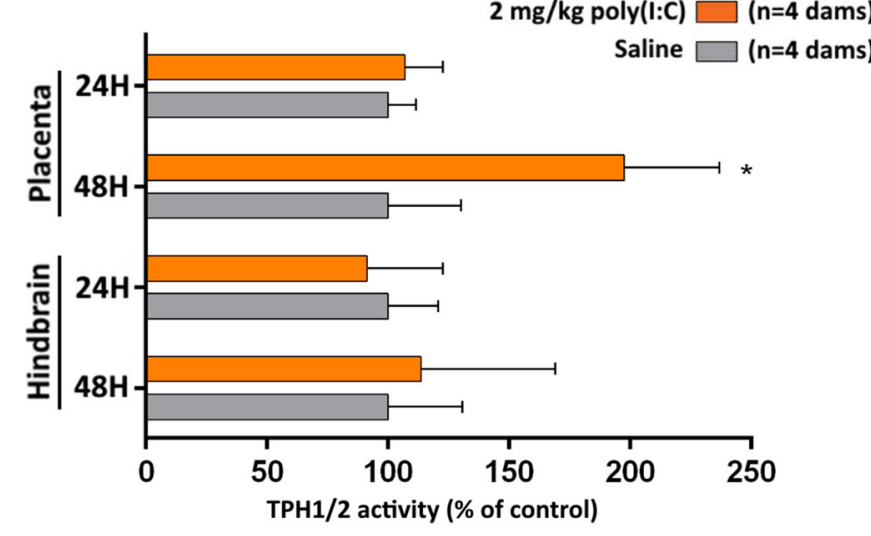

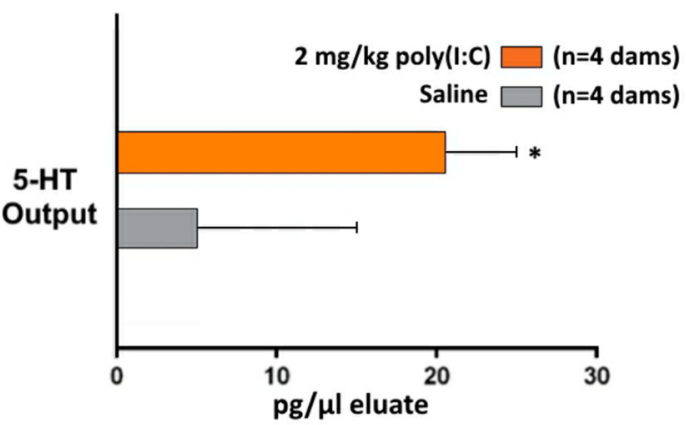

Figure 2. Maternal inflammation increases placental TPH1 enzymatic activity and ex vivo 5 -HT output to the fetus. $A$, Twenty-four and $48 \mathrm{~h}$ after saline (control) or poly(l:C) (2 mg/kg) injections at E12, TRP to 5-HTP conversion, which reflects TPH enzymatic activity, was measured in placentas (TPH1) and fetal hindbrains (TPH2). Maternal inflammation induces a significant increase in TPH1 activity over saline (control) level (measured in placental extracts from saline injected dams) at $48 \mathrm{~h}$ only. TPH2 activity in the hindbrain is unchanged at both the 24 and $48 \mathrm{~h}$ time points. ${ }^{*} p<0.05$, two-way ANOVA with Bonferroni correction. $B$, Ex vivo placental perfusions showing that significantly more 5 - $\mathrm{HT}$ is synthesized and released from the placenta $48 \mathrm{~h}$ after maternal poly $(\mathrm{l}: \mathrm{C})$ exposure compared with saline (control) exposure. ${ }^{*} p<0.05$, unpaired t test with Holm-Sidak correction. Error bars indicate SEM percentage change $(\boldsymbol{A})$ or $\operatorname{SD}(\boldsymbol{B}) \cdot n=3(\boldsymbol{A})$ or $n=1(\boldsymbol{B})$ placentas per dam.

Decreased 5-HT axon outgrowth in the fetal forebrain

In addition to increased placental output, elevated forebrain 5-HT tissue concentration could have resulted from increased endogenous serotonergic axon outgrowth into the region. To test this possibility, we measured serotonergic (5-HT-immunoreactive, 5-HT+) axon density systematically throughout the rostrocaudal extent of the fetal forebrain $48 \mathrm{~h}$ after maternal exposure to saline, poly(I:C), or poly(I:C) and the TPH inhibitor pCPA (Fig. 4A). When comparing sets of sections at matching rostrocaudal levels, densitometric analysis of fluorescence distribution showed a significant decrease of 5-HT+ axon density in the rostral two-thirds of the forebrain in the poly(I:C)-treated, but not the poly(I:C) + pCPA-treated group, compared with saline (Fig. $4 B$ ). The overall 5-HT+ axon density over the entire rostrocaudal axis was significantly decreased in the poly(I:C)treated group compared with saline, but not after the coadministration of poly(I:C) with pCPA (Fig. 4B; Mann-Whitney test, $U=60, p=0.0009)$. Furthermore, HPLC analyses showed that coadministration of pCPA prevents the accumulation of 5-HT in the fetal forebrain that is induced by poly $(\mathrm{I}: \mathrm{C})$ exposure alone versus the poly(I:C) + pCPA group $\left(t_{(6)}=4.94, p=0.002\right.$; saline group versus poly(I:C) + pCPA group: $t_{(6)}=1.81, p=0.119$; Fig. $4 C)$. These results show that the elevation of 5 -HT in the forebrain after mild inflammation is not due to increased serotonergic axon outgrowth into the region. Rather, the results suggest that elevated placental output of 5-HT after mild immune activation leads to increased extracellular 5-HT accumulation in the fetal forebrain that affect serotonergic axon rostral outgrowth negatively.

\section{Discussion}

Our results identify a novel molecular pathway by which maternal inflammation during pregnancy alters specific aspects of fetal brain development. We used a mild maternal immune challenge [2 mg/kg poly(I:C) administered i.p. at E12] with the following characteristics: (1) it does not lead to the accumulation of cytokines in the fetal brain, (2) it mimics clinically common mild inflammation with transient cytokine elevations in the maternal serum (Giovanoli et al., 2013; Meyer, 2014), and (3) it induces significant long-term brain and behavioral deficits in the adult offspring (Meyer et al., 2005; Meyer and Feldon, 2012). Importantly, whereas the mild immune challenge induced the expected transient IL-6 increase in the maternal serum, there was no evidence of cytokine accumulation in the fetal brain tissue (Fig. 1). This suggests, not only that mild subclinical maternal inflammation does not alter overall placental permeability to cytokines, but also that it primarily involves indirect effects on the fetal brain (Bergström, 2003; Tincani et al., 2005; Seong et al., 2008; Romero et al., 2014) that may be mediated in part by cytokine interactions with placental toll-like receptors (Girard et al., 2010).

Consistent with an indirect action of maternal inflammation on the fetal brain through alteration of placental function, our results show that low-dose poly(I:C) exposure affects placental TRP metabolism directly upstream of the fetus. The increase in 
A

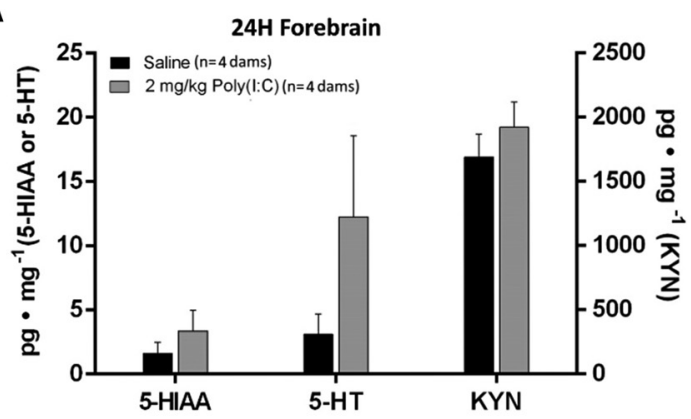

C

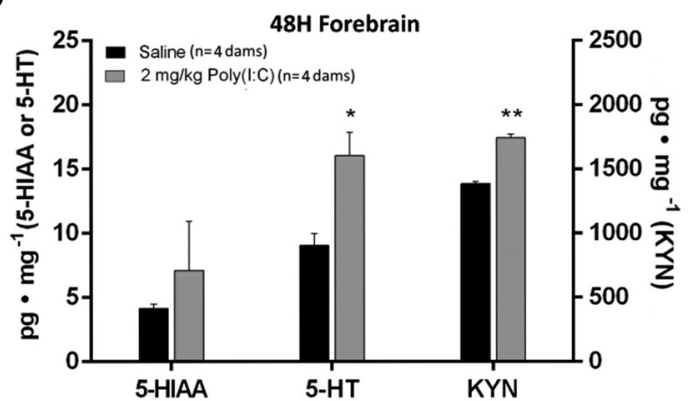

$\mathbf{E}$

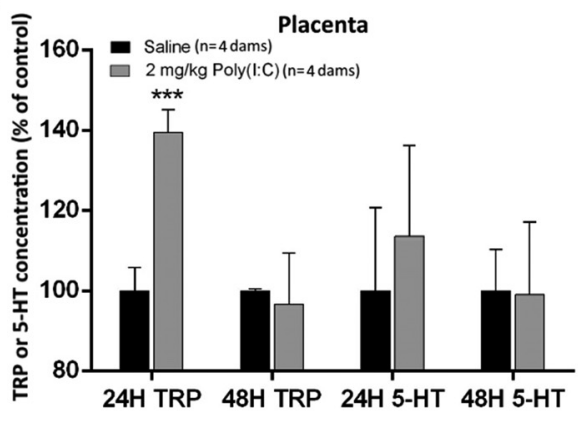

B
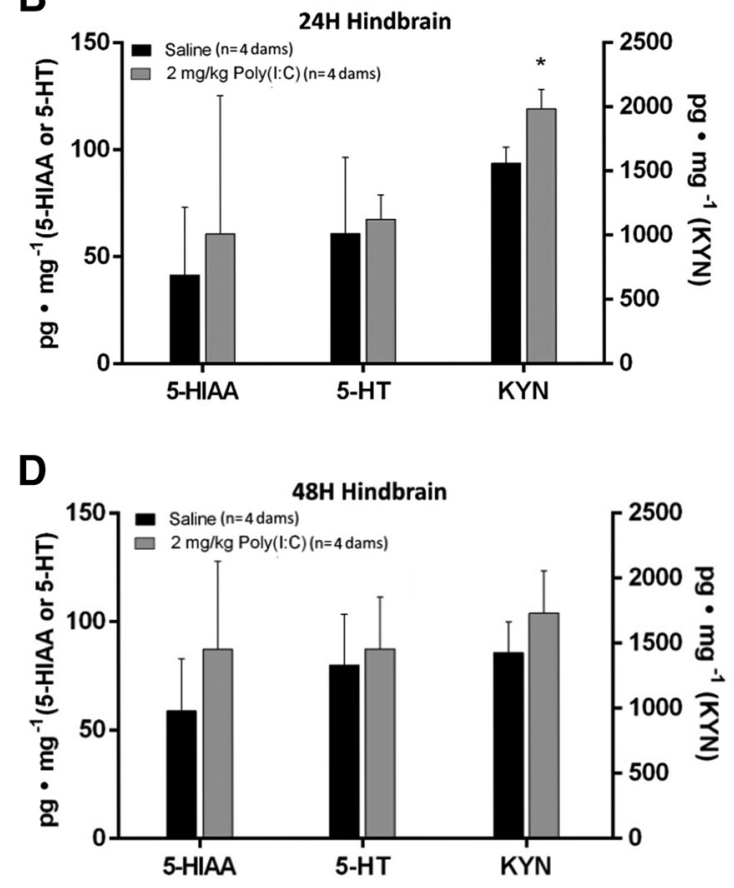

$\mathbf{F}$

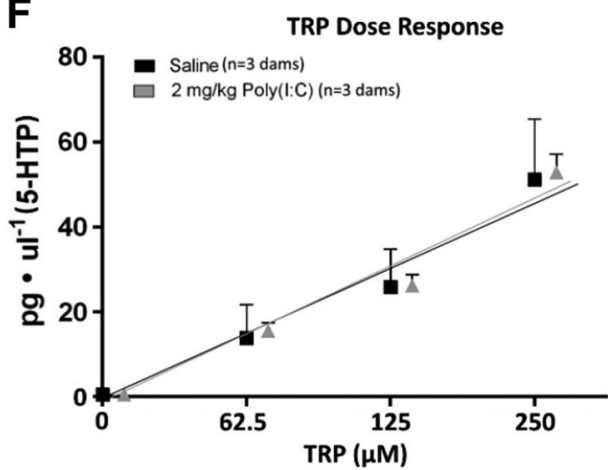

Figure 3. Maternal inflammation leads to increased tryptophan metabolites tissue concentration in the fetal brain. Inflammation was induced by poly(l:C) injection (2 mg/kg) at E12. Fetal brain tissue concentration of 5-HIAA, 5 -HT, and KYN were measured by HPLC. $\boldsymbol{A}, \boldsymbol{B}$, Maternal inflammation induces a significant increase of 5 -HT in the fetal forebrain $(\boldsymbol{A})$, but not hindbrain $(\boldsymbol{B}) 24 \mathrm{~h}$ after injection. KYN concentration is significantly increased in the fetal hindbrain only. $C, D$, Forty-eight hours after maternal poly(l:C) injection, 5-HT and KYN are significantly increased in the fetal forebrain $(\boldsymbol{C})$, but not hindbrain $(\boldsymbol{D})$. Brain 5-HIAA concentration is not significantly altered at any time point in either region. $\boldsymbol{E}$, Placental TRP concentration is transiently increased $24 \mathrm{~h}$ but not $48 \mathrm{~h}$ after maternal poly(l:C) exposure. $\boldsymbol{F}$, Rate of placental 5 -HTP synthesis in vitro is correlated linearly to increasing input concentrations of TRP in both saline (control)- and poly(l:C)-exposed dams. ${ }^{*} p<0.05,{ }^{* *} p<0.005$, two-way ANOVA with Bonferroni correction. Error bars indicate SD. $n=3-5$ placentas per dam.

placental Ido1 gene expression in response to inflammation demonstrated here is consistent with previously published studies (Shayda et al., 2009; Wang et al., 2010) and, together with cytokine measures, confirms that the injection of low-dose poly(I:C) at E12 induces an inflammatory response in the mother that is attenuated locally in the placenta. This upregulation of the IDO1 pathway is critical for the localized suppression of the maternal immune response to protect the semiallogeneic fetus from rejection (Du et al., 2014). It was hypothesized recently that such upregulation would lead to decreased TRP substrate availability for the competing TPH1 pathway, ultimately decreasing placental output of 5-HT to the developing fetal brain (Sato, 2013). Contrary to this hypothesis, our results reveal a transient increase of TRP in the placenta $24 \mathrm{~h}$ after poly(I:C) exposure (Fig. $3 F$ ). Simultaneously, 5-HT tissue concentration is increased in the fetal forebrain (Fig. 3A), but not the placenta (Fig. 3E). Because the maternal blood compartment represents $\sim 30 \%$ of the placental volume (Coan et al., 2008, 2010), these data suggest that the maternal TRP, but not 5-HT, blood level is increased $24 \mathrm{~h}$ after poly(I:C) injection. Importantly, placental TPH1 enzymatic activity is normal at the $24 \mathrm{~h}$ time point (Fig. $2 \mathrm{~A}$ ); however, doseresponse studies (Fig. $3 F$ ) show that increasing concentrations of TRP substrate (up to fourfold above the normal physiological concentrations of $\sim 60 \mu \mathrm{M}$; Schröcksnadel et al., 2006) induce a linear increase of 5-HT synthesis. By $48 \mathrm{~h}$ after poly(I:C) injection, the placental TRP concentration returns to control level (Fig. 3E), whereas placental TPH1 enzymatic activity is increased significantly compared with saline-injected controls (Fig. 2A). Therefore, two different mechanisms contribute successively to the elevation of fetal forebrain 5-HT measured 24 and $48 \mathrm{~h}$ after maternal poly(I:C) injection: (1) $24 \mathrm{~h}$ after induction of maternal inflammation, the transient elevation of maternal blood/placental TRP leads to increased output of placental 5-HT to the fetus and (2) at $48 \mathrm{~h}$, the placental TRP concentration has returned back to normal levels (Fig. $3 E$ ) but TPH1 enzymatic activity is increased (Fig. 2A), leading to increased placental 5-HT output to 
A

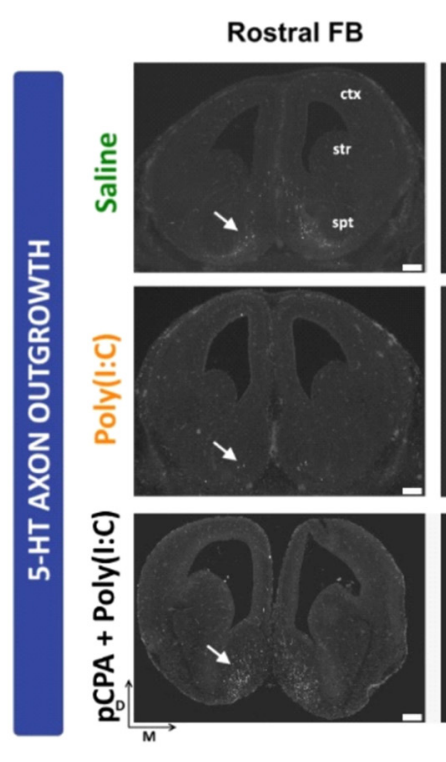

Medial FB
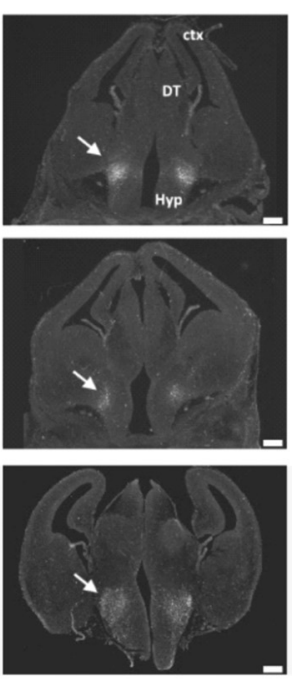
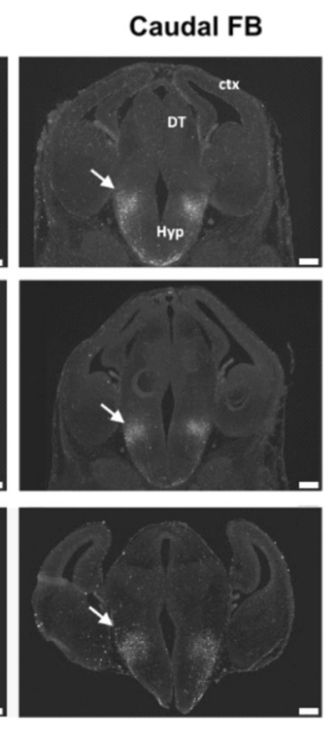

B

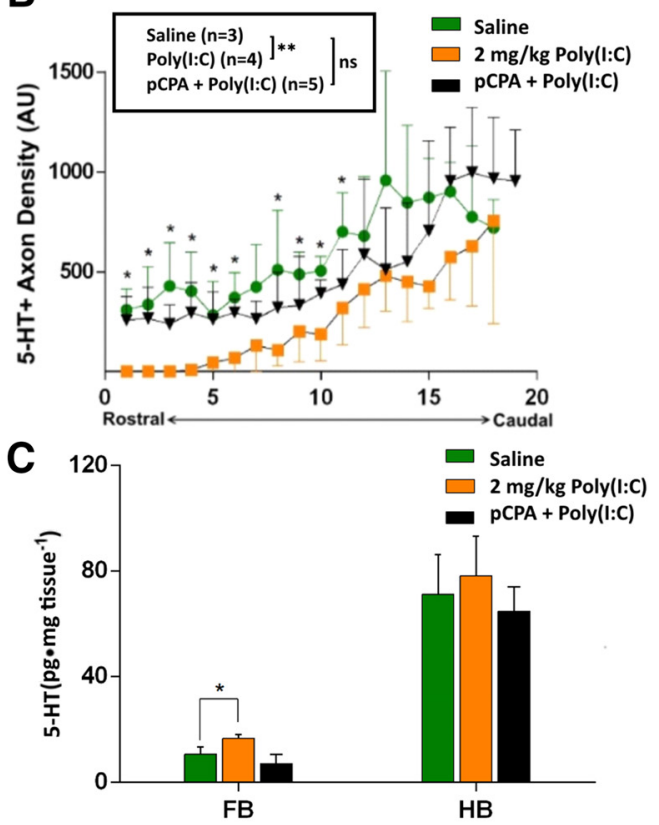

D

Placenta

Fetal Brain
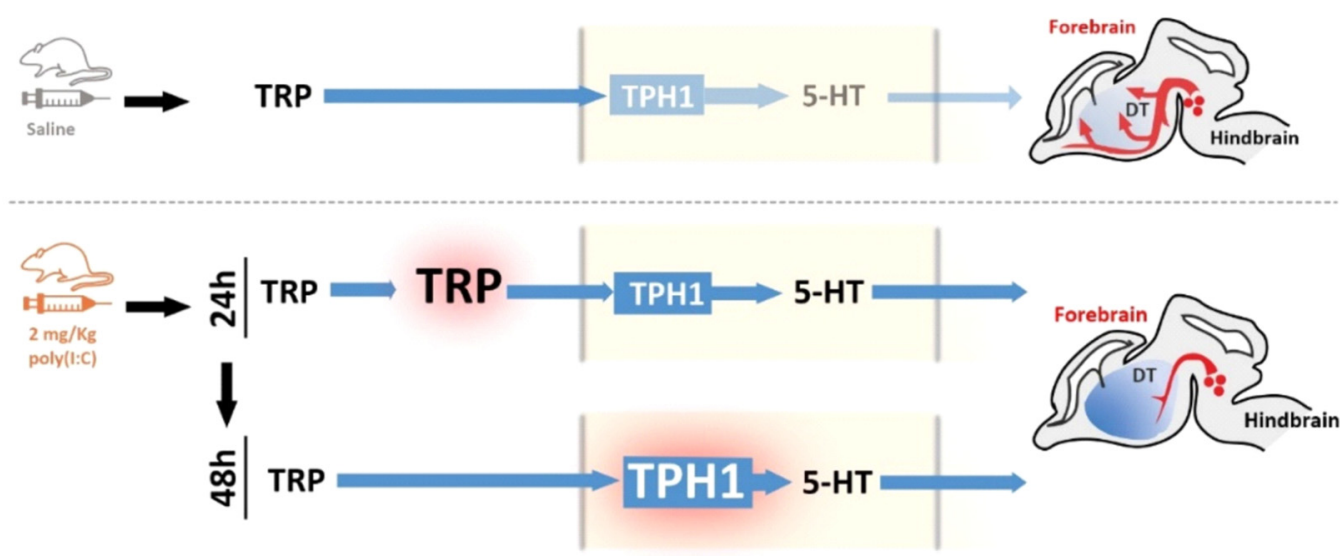

Figure 4. Maternal inflammation disrupts fetal serotonergic axon outgrowth. $A, \mathrm{HC}$ analysis of serotonergic axons in fetal brains $48 \mathrm{~h}$ after maternal exposure to either saline or $2 \mathrm{mg} / \mathrm{kg}$ poly(l:C) reveals blunted outgrowth of serotonergic axons in a caudal to rostral gradient within the fetal forebrain when comparing saline (control) with poly(l:C) treatments. This effect is not observed in the group coadministered with poly $(\mathrm{l}: \mathrm{C})$ and the TPH inhibitor pCPA [pCPA + poly(l:C); bottom panels]. B, Quantification of 5-HT + axons density (normalized fluorescence intensity) throughout the rostrocaudal extent of E14 fetal forebrains obtained from saline (control)-, poly(l:C)--, or poly(l:C) + pCPA-treated dams $48 \mathrm{~h}$ after exposure. ${ }^{*} p<0.05,{ }^{* *} p<0.005, \mathrm{~ns}$, not significant, Mann-Whitney $U$ test. C, $5-\mathrm{HT}$ is significantly increased in the fetal forebrain (FB) $48 \mathrm{~h}$ after maternal poly $(\mathrm{l}: \mathrm{C})$, but not poly $(\mathrm{l}: \mathrm{C})+\mathrm{pCPA}$ injection; hindbrain (HB) 5 -HT concentration is not affected significantlyin either group. ${ }^{*} p<0.05$, unpaired $t$ test with Holm-Sidak correction. $n=4$ dams per group. $\boldsymbol{D}$, Mild maternal inflammation induces a rapid increase in TRP metabolism through successively transient elevation of maternal blood/placental TRP concentration $(24 \mathrm{~h})$ followed by increased placental TPH1 enzymatic activity (48 $\mathrm{h}$ ). This results in a sustained increase in fetal forebrain 5-HT tissue concentration and abnormal serotonergic axonal circuit formation. D, Dorsal; M, medial; Ctx, cortex; Str, striatum; Spt, septum; DT, dorsal thalamus; Hyp, hypothalamus. Error bars indicate SD. Scale bars, $200 \mu \mathrm{m}$.

the fetus (Fig. 2B). This chronological sequence of molecular changes results in a sustained elevation of fetal brain 5-HT lasting for at least $48 \mathrm{~h}$ after induction of maternal inflammation. The 5 -HTP intermediate metabolic product produced by placental TPH1 activity (Fig. 3F) might also get converted to 5-HT within the fetal forebrain; however, 5-HTP was not detected in the fetal forebrain at either time point, suggesting that the contribution of this pathway to the increase in 5-HT concentration is minimal. The results also suggest that transfer of maternal blood 5-HT to the fetus is unlikely to contribute to elevated fetal brain 5-HT levels. Indeed, poly(I:C) injections do not alter total maternal blood/placental 5-HT concentration significantly (Fig. 3E) and, to our knowledge, there is no evidence of active transport of 5-HT across the placenta. Early studies (Robson and Senior, 1964) and more recent studies (Bonnin et al., 2011) show that maternal blood 5-HT does not cross to the fetal compartment to a measurable extent. In fact, the absence of active maternalfetal 5-HT transport during this time period (E12-E14) may be consistent with the lack of 5-HT-specific transporter SERT expression in early pregnancy in the mouse placenta (Verhaagh et al., 2001). Importantly, the increase of forebrain 5 -HT is not associated with a decrease in 5-HIAA concentration, indicating that it does not result from decreased 5-HT degradation in the fetal brain. 
The direct in vivo measure of increased 5-HT output from the placenta to the fetal blood compartment in response to inflammatory challenge was not possible due to the very small volumes of blood collected at E13/14. However, the data indicate that the elevation of fetal forebrain 5-HT concentration measured after the maternal immune challenge results directly from increased placental 5-HT output. First, maternal inflammation upregulates TRP substrate availability and TPH1 enzymatic activity in the placenta, but not TPH2 activity in the fetal hindbrain (Fig. 2A). Second, the increase of 5-HT tissue concentration is significant in the fetal forebrain, but not hindbrain, where endogenous 5-HT neuronal cell bodies and proximal axons are located. Third, immunohistochemical analysis shows that maternal inflammation induces a significant decrease, not increase, of 5-HT axon outgrowth specifically into the rostral forebrain (Fig. 4B). Fourth, coadministration of the selective TPH inhibitor PCPA prevents, not only the accumulation of 5-HT, but also the blunting of endogenous serotonergic axon outgrowth induced by maternal inflammation in the fetal forebrain. This effect took place between E12 and E14, a period of active serotonergic axon outgrowth into the rostral forebrain (Lidov and Molliver, 1982; Wallace and Lauder, 1983). The simultaneous increase in total tissue 5-HT concentration and decrease of 5-HT axons density in the forebrain indicates that, at early stages of development (before E14), tissue concentrations of 5-HT measured by HPLC reflect mainly extracellular rather than immunohistochemically visible axonal 5-HT. A similar observation was made in the fetal forebrain of E14 Pet-1 knock-out embryos, in which most of the rostral forebrain serotonergic axon bundle is missing but which contain a normal tissue concentration of 5-HT (Bonnin et al., 2007). Increased extracellular 5-HT of placental origin may in fact affect endogenous serotonergic axon outgrowth directly in the rostral forebrain. Indeed, earlier studies showed that extracellular 5-HT concentrations regulate 5-HT axon outgrowth through subsets of 5-HT autoreceptors expressed either on dorsal raphe 5-HT neuron cell bodies or axons (Daubert and Condron, 2010). This suggests that the blunted rostral serotonergic axon outgrowth observed after maternal immune challenge may be a direct consequence of elevated concentrations of exogenous placental 5-HT reaching the forebrain.

Together, these findings indicate that a mild and acute maternal immune challenge disrupts placental conversion of TRP to 5-HT upstream of the fetal brain, which ultimately affects specific aspects of fetal neurodevelopment (Fig. 4A,B). Importantly, although the simultaneous increase of TRP metabolic flux through both the IDO1 and TPH1 pathways in the placenta in response to maternal inflammation provides an important immunesuppressive protection for the fetus, it also leads to increased fetal brain exposure to elevated concentrations of 5-HT. Such an increase in ligand concentration affects important developmental processes in the fetal brain that are normally modulated by $5-\mathrm{HT}$ at early stages of pregnancy. A mild maternal inflammation triggered by low-dose poly(I:C) exposure, similar to the challenge used in the current study, was shown to have long-term effects on offspring brain function and behavior, including disruption of latent inhibition, spatial working memory impairment, and reduced spatial exploration (Meyer and Feldon, 2012). Although these studies included doses and routes of administration for poly $(\mathrm{I}: \mathrm{C})$ similar to those used in the present study, results indicated that offspring behavioral outcomes are dose dependent and potentially mouse strain dependent (Meyer and Feldon, 2012). Nevertheless, it appears that prenatal inflammation can lead to increased anxiety and depression-like behaviors in the offspring, behaviors that are influenced by serotonergic function (Butkevich et al., 2003; Enayati et al., 2012; Lin et al., 2012). The possibility that the effect of maternal inflammation on early serotonergic development has long-term consequences on 5-HT-dependent behaviors is also supported by studies showing that low-dose poly(I:C) exposure during pregnancy decreases serotonergic tone in specific brain regions of the adult offspring, such as the nucleus accumbens and hippocampus (Winter et al., 2009). However, to what extent the early specific disruptions of serotonergic circuit formation reported here contribute to these long-term alterations of offspring brain function requires additional characterization. Further studies on the effects of infectious agents on placentally derived modulators of neurodevelopment are warranted, particularly in view of recent infectious diseases outbreaks (such as H1N1 influenza or Zika virus) suggesting that pregnant women and their fetuses are high-risk groups for severe and long-lasting complications (Omer and Beigi, 2016).

\section{References}

Bell MJ, Hallenbeck JM (2002) Effects of intrauterine inflammation on developing rat brain. J Neurosci Res 70:570-579. CrossRef Medline

Bergström S (2003) Infection-related morbidities in the mother, fetus and neonate. J Nutr 133:1656S-1660S. Medline

Bonnin A, Levitt P (2011) Fetal, maternal, and placental sources of serotonin and new implications for developmental programming of the brain. Neuroscience 197:1-7. CrossRef Medline

Bonnin A, Torii M, Wang L, Rakic P, Levitt P (2007) Serotonin modulates the response of embryonic thalamocortical axons to netrin-1. Nat Neurosci 10:588-597. CrossRef Medline

Bonnin A, Goeden N, Chen K, Wilson ML, King J, Shih JC, Blakely RD, Deneris ES, Levitt P (2011) A transient placental source of serotonin for the fetal forebrain. Nature 472:347-350. CrossRef Medline

Brummelte S, McGlanaghy E, Bonnin A, Oberlander TF (2016) Developmental changes in serotonin signaling: Implications for early brain function, behavior and adaptation. Neuroscience pii: S03064522(16)00177-9. CrossRef Medline

Butkevich IP, Khozhai LI, Mikhailenko VA, Otellin VA (2003) Decreased serotonin level during pregnancy alters morphological and functional characteristics of tonic nociceptive system in juvenile offspring of the rat. Reprod Biol Endocrinol 1:96. CrossRef Medline

Coan PM, Angiolini E, Sandovici I, Burton GJ, Constância M, Fowden AL (2008) Adaptations in placental nutrient transfer capacity to meet fetal growth demands depend on placental size in mice. J Physiol 586: 4567-4576. CrossRef Medline

Coan PM, Vaughan OR, Sekita Y, Finn SL, Burton GJ, Constancia M, Fowden AL (2010) Adaptations in placental phenotype support fetal growth during undernutrition of pregnant mice. J Physiol 588:527-538. CrossRef Medline

Daubert EA, Condron BG (2010) Serotonin: a regulator of neuronal morphology and circuitry. Trends Neurosci 33:424-434. CrossRef Medline

Du MR, Guo PF, Piao HL, Wang SC, Sun C, Jin LP, Tao Y, Li YH, Zhang D, Zhu R, Fu Q, Li DJ (2014) Embryonic trophoblasts induce decidual regulatory $\mathrm{T}$ cell differentiation and maternal-fetal tolerance through thymic stromal lymphopoietin instructing dendritic cells. J Immunol 192: 1502-1511. CrossRef Medline

Elovitz MA, Brown AG, Breen K, Anton L, Maubert M, Burd I (2011) Intrauterine inflammation, insufficient to induce parturition, still evokes fetal and neonatal brain injury. Int J Dev Neurosci 29:663-671. CrossRef Medline

Enayati M, Solati J, Hosseini M-H, Shahi HR, Saki G, Salari AA (2012) Maternal infection during late pregnancy increases anxiety- and depressionlike behaviors with increasing age in male offspring. Brain Res Bull 87: 295-302. CrossRef Medline

Gaspar P, Cases O, Maroteaux L (2003) The developmental role of serotonin: news from mouse molecular genetics. Nat Rev Neurosci 4: 1002-1012. CrossRef Medline

Giovanoli S, Engler H, Engler A, Richetto J, Voget M, Willi R, Winter C, Riva MA, Mortensen PB, Feldon J, Schedlowski M, Meyer U (2013) Stress in puberty unmasks latent neuropathological consequences of prenatal immune activation in mice. Science 339:1095-1099. CrossRef Medline 
Girard S, Tremblay L, Lepage M, Sébire G (2010) IL-1 receptor antagonist protects against placental and neurodevelopmental defects induced by maternal inflammation. J Immunol 184:3997-4005. CrossRef Medline

Goeden N, Bonnin A (2013) Ex vivo perfusion of mid-to-late-gestation mouse placenta for maternal-fetal interaction studies during pregnancy. Nat Protoc 8:66-74. CrossRef Medline

Hervé C, Beyne P, Jamault H, Delacoux E (1996) Determination of tryptophan and its kynurenine pathway metabolites in human serum by highperformance liquid chromatography with simultaneous ultraviolet and fluorimetric detection. J Chromatogr B Biomed Appl 675:157-161. CrossRef Medline

Janusonis S, Anderson GM, Shifrovich I, Rakic P (2006) Ontogeny of brain and blood serotonin levels in 5-HT receptor knockout mice: potential relevance to the neurobiology of autism. J Neurochem 99:1019-1031. CrossRef Medline

Lidov HG, Molliver ME (1982) An immunohistochemical study of serotonin neuron development in the rat: ascending pathways and terminal fields. Brain Res Bull 8:389-430. CrossRef Medline

Limperopoulos C, Bassan H, Sullivan NR, Soul JS, Robertson RL Jr, Moore M, Ringer SA, Volpe JJ, du Plessis AJ (2008) Positive screening for autism in ex-preterm infants: prevalence and risk factors. Pediatrics 121:758-765. CrossRef Medline

Lin YL, Lin SY, Wang S (2012) Prenatal lipopolysaccharide exposure increases anxiety-like behaviors and enhances stress-induced corticosterone responses in adult rats. Brain Behav Immun 26:459-468. CrossRef Medline

Livak KJ, Schmittgen TD (2001) Analysis of relative gene expression data using real-time quantitative PCR and the 2(-delta delta $\mathrm{C}(\mathrm{T})$ ) method. Methods 25:402-408. CrossRef Medline

Lund BT, Ashikian N, Ta HQ, Chakryan Y, Manoukian K, Groshen S, Gilmore W, Cheema GS, Stohl W, Burnett ME, Ko D, Kachuck NJ, Weiner LP (2004) Increased CXCL8 (IL-8) expression in multiple sclerosis. J Neuroimmunol 155:161-171. CrossRef Medline

Mellor AL, Munn DH (2001) Tryptophan catabolism prevents maternal T cells from activating lethal anti-fetal immune responses. J Reprod Immunol 52:5-13. CrossRef Medline

Meyer U (2014) Prenatal Poly(I:C) exposure and other developmental immune activation models in rodent systems. Biol Psychiatry 75:307-315. CrossRef Medline

Meyer U, Feldon J (2012) To poly(I:C) or not to poly(I:C): advancing preclinical schizophrenia research through the use of prenatal immune activation models. Neuropharmacology 62:1308-1321. CrossRef Medline

Meyer U, Feldon J, Schedlowski M, Yee BK (2005) Towards an immunoprecipitated neurodevelopmental animal model of schizophrenia. Neurosci Biobehav Rev 29:913-947. CrossRef Medline

Munn DH, Zhou M, Attwood JT, Bondarev I, Conway SJ, Marshall B, Brown C, Mellor AL (1998) Prevention of allogeneic fetal rejection by tryptophan catabolism. Science 281:1191-1193. CrossRef Medline

Omer SB, Beigi RH (2016) Pregnancy in the time of Zika: addressing barriers for developing vaccines and other measures for pregnant women. JAMA 315:1227-1228. CrossRef Medline

Patterson PH (2002) Maternal infection: window on neuroimmune interactions in fetal brain development and mental illness. Curr Opin Neurobiol 12:115-118. CrossRef Medline

Patterson PH (2009) Immune involvement in schizophrenia and autism: etiology, pathology and animal models. Behav Brain Res 204:313-321. CrossRef Medline
Robson JM, Senior JB (1964) The 5-hydroxytryptamine content of the placenta and foetus during pregnancy in mice. Br J Pharmacol Chemother 22:380-391. CrossRef Medline

Romero R, Miranda J, Chaemsaithong P, Chaiworapongsa T, Kusanovic JP, Dong Z, Ahmed AI, Shaman M, Lannaman K, Yoon BH, Hassan SS, Kim CJ, Korzeniewski SJ, Yeo L, Kim YM (2014) Sterile and microbialassociated intra-amniotic inflammation in preterm prelabor rupture of membranes. J Matern Fetal Neonatal Med 28:1394-1409. CrossRef Medline

Sato K (2013) Placenta-derived hypo-serotonin situations in the developing forebrain cause autism. Med Hypotheses 80:368-372. CrossRef Medline

Schröcksnadel K, Wirleitner B, Winkler C, Fuchs D (2006) Monitoring tryptophan metabolism in chronic immune activation. Clin Chim Acta 364:82-90. CrossRef Medline

Seong HS, Lee SE, Kang JH, Romero R, Yoon BH (2008) The frequency of microbial invasion of the amniotic cavity and histologic chorioamnionitis in women at term with intact membranes in the presence or absence of labor. Am J Obstet Gynecol 199:375.e1-375.e5. CrossRef Medline

Shayda H, Mahmood JT, Ebrahim T, Jamileh G, Golnaz Ensieh KS, Parivash D, Leila BY, Mohammad Mehdi A, Amir Hassan Z (2009) Indoleamine 2,3-dioxygenase (IDO) is expressed at feto-placental unit throughout mouse gestation: an immunohistochemical study. J Reprod Infertil 10: 177-183. Medline

Stolp HB, Turnquist C, Dziegielewska KM, Saunders NR, Anthony DC, Molnár Z (2011) Reduced ventricular proliferation in the foetal cortex following maternal inflammation in the mouse. Brain 134:3236-3248. CrossRef Medline

Tincani A, Rebaioli CB, Frassi M, Taglietti M, Gorla R, Cavazzana I, Faden D, Taddei F, Lojacono A, Motta M, Trepidi L, Meroni P, Cimaz R, Ghirardello A, Doria A, Pisoni MP, Muscarà M, Brucato A; Pregnancy Study Group of Italian Society of Rheumatology (2005) Pregnancy and autoimmunity: maternal treatment and maternal disease influence on pregnancy outcome. Autoimmun Rev 4:423-428. CrossRef Medline

van Kleef ES, Gaspar P, Bonnin A (2012) Insights into the complex influence of 5-HT signaling on thalamocortical axonal system development. Eur J Neurosci 35:1563-1572. CrossRef Medline

Verhaagh S, Barlow DP, Zwart R (2001) The extraneuronal monoamine transporter Slc22a3/Orct3 co-localizes with the Maoa metabolizing enzyme in mouse placenta. Mech Dev 100:127-130. CrossRef Medline

Wallace JA, Lauder JM (1983) Development of the serotonergic system in the rat embryo: an immunocytochemical study. Brain Res Bull 10:459_ 479. CrossRef Medline

Wang X, Stridh L, Li W, Dean J, Elmgren A, Gan L, Eriksson K, Hagberg H, Mallard C (2009) Lipopolysaccharide sensitizes neonatal hypoxicischemic brain injury in a MyD88-dependent manner. J Immunol 183: 7471-7477. CrossRef Medline

Wang Y, Liu H, McKenzie G, Witting PK, Stasch JP, Hahn M, Changsirivathanathamrong D, Wu BJ, Ball HJ, Thomas SR, Kapoor V, Celermajer DS, Mellor AL, Keaney JF Jr, Hunt NH, Stocker R (2010) Kynurenine is an endothelium-derived relaxing factor produced during inflammation. Nat Med 16:279-285. CrossRef Medline

Winter C, Djodari-Irani A, Sohr R, Morgenstern R, Feldon J, Juckel G, Meyer U (2009) Prenatal immune activation leads to multiple changes in basal neurotransmitter levels in the adult brain: implications for brain disorders of neurodevelopmental origin such as schizophrenia. Int J Neuropsychopharmacol 12:513-524. CrossRef Medline 